\title{
MAKNA KATA DALAM BIDANG STRUKTUR BANGUNAN YANG BERASOSIASI DENGAN BIDANG BIOLOGIS
}

\author{
Erlyn Rosalina $^{1, \varpi)}$, Linda Sari Wulandari ${ }^{2)}$ \\ ${ }^{1}$ Jurusan Administrasi Niaga, Politeknik Negeri Jakarta \\ ${ }^{2}$ Jurusan Teknik Sipil, Politeknik Negeri Jakarta \\ e-mail: ${ }^{1}$ erlyn.rosalina@bisnis.pnj.ac.id, ${ }^{2}$ linda.sari.wulandari@sipil.pnj.ac.id
}

\begin{abstract}
This research is entitled, "The Meaning of Words in the Field of Building Structures Associated with the Biological Field". This study aims to analyze the meaning of various terms, in particular, words in the field of building structures that contain biological elements. Researchers used descriptive qualitative methods. Data collection was done by observing method and note taking technique. The data in this study are in the form of a list of terms contained in the SNI for loading and SNI for reinforced concrete. The theory of semantic studies regarding the shift in meaning, especially associative meaning, becomes the theory used in research. The results show that in the field of civil engineering there are the same words as elements of the term biological. Some of the associated words include diaphragm, reinforcement, and tendons. These three words are used because of developments in science and technology, differences in usage, and development of terms. These three factors are caused by the need to use terms in the field of civil engineering which contain elements of similarity in nature to biological elements
\end{abstract}

Keywords : Semantic; Association; Building Structure; Civil Engineering; Biological Terms

\begin{abstract}
ABSTRAK
Penelitian ini berjudul, "Makna Kata dalam Bidang Struktur Bangunan yang Berasosiasi dengan Bidang Biologis”. Penelitian bertujuan untuk menganalisis makna dari berbagai istilah, khususnya, kata-kata dalam bidang struktur bangunan yang mengandung unsur biologis. Peneliti menggunakan metode kualitatif deskriptif. Pengumpulan data dilakukan dengan metode simak dan teknik catat. Data dalam penelitian ini berupa daftar istilah yang terdapat dalam SNI pembebanan dan SNI beton bertulang. Teori kajian semantik mengenai pergeseran makna, khususnya makna asosiatif, menjadi teori yang digunakan dalam penelitian. Hasil penelitian menunjukkan bahwa di dalam bidang teknik sipil terdapat kata yang sama dengan unsur istilah biologis. Beberapa kata yang berasosiasi di antaranya diafragma, tulangan, dan tendon. Ketiga kata tersebut digunakan karena adanya perkembangan dalam bidang ilmu dan teknologi, perbedaan bidang pemakaian, dan pengembangan istilah. Ketiga faktor tersebut disebabkan oleh adanya kebutuhan penggunaan istilah dalam bidang teknik sipil yang mengandung unsur kemiripan sifat dengan unsur biologis.
\end{abstract}

Kata kunci : Semantik; Asosiasi; Struktur Bangunan; Teknik Sipil; Istilah Biologis.

\section{PENDAHULUAN}

\section{Latar Belakang}

Bahasa sebagai alat komunikasi berfungsi untuk menyampaikan pesan atau makna oleh seseorang kepada orang lain. Tarigan (2015: 7) menyatakan bahwa semantik adalah telaah mengenai makna. Makna dalam bahasa berkaitan dengan kata, kalimat, dan konteks. Ada dua aspek kata sebagai satuan dari pembendaharaan kata, yaitu aspek bentuk atau ekspresi dan aspek isi atau makna (Keraf, 2010: 25). Singkatnya, kata yang diucapkan adalah ekspresi atau bentuknya, sedangkan reaksi pendengar dan pembaca adalah makna atau isinya. Selain itu, kata dapat mengalami pergeseran makna jika dikaitkan dari satu bidang dengan bidang lain. Dalam penelitian ini, akan dijabarkan pergeseran makna pada bidang teknik sipil yang ditemui dalam SNI 1727 tentang pembebanan dan SNI 032847 tentang beton bertulang dengan unsur istilah unsur biologis.

Teknik sipil merupakan salah satu cabang ilmu teknik. Cabang ilmu teknik ini mempelajari tentang bagaimana merancang, membangun, dan juga 
merenovasi bangunan, gedung, serta infrastuktur. Bidang ini memiliki daftar istilah yang dapat dikaji dari segi bahasanya. Beberapa istilah dalam teknik sipil juga memiliki kata yang sama dengan istilah bidang lain, dalam hal ini adalah unsur istilah biologis.

Biologis dalam KBBI (2016) memiliki arti bersangkutan dengan biologi. Biologi berkenaan dengan ilmu tentang keadaan dan sifat makhluk hidup (manusia, binatang, tumbuh-tumbuhan); ilmu hayat. Di dalam unsur istilah biologi, terdapat beberapa kata yang berasosiasi dengan kata dalam bidang teknik sipil.

Kata-kata yang tersimpan di dalam leksikon dan saling berhubungan dengan makna kata lainnya disebut dengan asosiasi kata. Ayuningsih (2012) berpendapat bahwa terdapat dua asosiasi kata, yaitu asosiasi kata berdasarkan bentuk dan maknanya. Di dalam penelitiannya, Widijayanto berpendapat bahwa makna asosiatif merupakan perlambang-perlambang yang sering digunakan dalam masyarakat. Jika ditinjau lebih dalam, ada kaitan dengan makna sebenarnya walau sudah mengalami pergeseran makna dari makna yang sebenarnya. Hal ini didukung oleh pernyataan Sudaryat (2008: 61), yaitu menurutnya asosisasi atau persamaan makna adalah perubahan makna yang terjadi akibat persamaan sifat antara dua kata atau lebih. Hal yang sama juga dikemukakan oleh Tarigan (2009: 90) yang menyatakan bahwa asosiasi merupakan adanya perubahan makna yang terjadi akibat persamaan sifat. Dari pernyataan-pernyataan tersebut dapat dikatakan bahwa kata dapat berasosiasi dengan kata lain jika dilihat dan digali lebih dalam maknanya serta hal tersebut terjadi akibat memiliki persamaan sifat di antara makna dari kata yang berasosiasi tersebut.

Penelitian sebelumnya yang membahas mengenai kajian semantik, khususnya berkaitan dengan asosiasi makna telah dilakukan oleh Widijayanto (2017) yang membahas makna konseptual dan asosiatif dengan judul "Makna Konseptual dan Asosiatif dalam Teks Lagu Sheila On 7”. Selain itu peneliti lain, Ayuningsih (2012) juga telah melakukan penelitian asosiasi kata pada mahasiswa semester II Angkatan 2011 Sastra Inggris Universitas Padjajaran. Karena memiliki tema yang sama, yaitu mengenai kajian semantik, khusunya dalam ranah asosiasi makna, makan penelitian yang dilakukan oleh Widijayanto dan Ayuningsih dapat menjadi acuan dalam menganalisis data penelitian.

\section{Tujuan dan Manfaat}

Tujuan penelitian ini adalah agar pembaca memahami perbedaan makna dari kata yang memiliki kesamaan dalam penulisan. Kesamaan kata di bidang berbeda akan berdampak pada perbedaan makna. Walaupun, jika ditelusuri lebih mendalam, kesaamaan kata ini memiliki asosiasi dalam makna. Manfaat dari penelitian ini adalah menjadi bahan pemahaman makna yang dapat digunakan di dua bidang, yaitu bidang teknis sipil dan biologi. Pemahaman makna ini akan mempermudah pembaca dalam memahami perbedaan makna dalam satu kata yang sama.

\section{Rumusan Masalah}

1. Kata apa saja yang memiliki kesamaan baik dalam bidang sturktur bangunan dan biologis?

2. Bagaimana proses asosiasi makna pada kata dalam bidang sturktur bangunan dan biologis?

\section{METODE PENELITIAN}

Metode yang digunakan dalam penelitian ini adalah metode kualitatif dengan pendekatan deskriptif. Metode yang digunakan untuk mencari unsur-unsur, ciri-ciri, dan sifat-sifat suatu fenomena disebut juga penelitian deskriptif (Sugiyono, 2012: 2). Metode ini dimulai 


\begin{abstract}
dengan mengumpulkan data, menganalisis data, dan menginterpretasikannya. Secara sistematis, faktual dan akurat, metode ini sangat cocok digunakan untuk mendeskripsikan dan menggambarkan mengenai sifat, fakta, dan hubungan dengan fenomena yang diteliti. Kajian kepustakaan digunakan untuk mengumpulkan data. Peneliti mengambil data dari SNI 1727 tentang pembebanan dan SNI 032847 tentang beton bertulang bidang teknik sipil berupa kata-kata yang memiliki persamaan antara bidang teknik sipil dan istilah biologis. Kata-kata tersebut berasosiasi dari segi maknanya melalui penjabaran makna yang lebih mendalam.
\end{abstract}

\section{HASIL DAN PEMBAHASAN}

Pada penilitian ini, penulis membatasi beberapa kata yang ada pada unsur istilah biologis. Analisis kata difokuskan ke dalam ranah semantik melalui penjabaran makna yang lebih mendalam, khususnya asosiasi makna bidang teknik sipil dengan istilah unsur biologis. Dari hasil pengumpulan data, terdapat tiga kata yang berasosiasi, di antaranya kata diafragma yang terdapat dalam SNI 1727 tentang pembebanan serta kata tendon dan tulangan dalam SNI 032847 tentang beton bertulang.

Data 1: Diafragma (SNI 1727)

Dalam bidang stuktur bangunan teknik sipil, diafragma memiliki makna atap, lantai, membran atau sistem bresing yang berfungsi menyalurkan gaya-gaya lateral ke elemen penahan vertikal. Kata diafragma ditekankan pada kata membran. Membran memiliki makna leksikal yang terdapat dalam KBBI, yaitu selaput, kulit tipis, atau lembaran bahan tipis yang merupakan pemisah.

Di dalam KBBI (2016), diafragma merupakan kata benda yang artinya sekat antara rongga dada dan rongga perut (pada tubuh). Diafragma dalam istilah unsur biologi ditekankan pada kata sekat.
Sekat adalah sesuatu seperti dinding, kerai, dan sebagainya untuk membatasi atau memisahkan ruang (menjadi berpetak-petak). Saat dikaji lebih mendalam, kedua bidang itu sama-sama memiliki kata dasar yang sama, yaitu pisah melalui kata memisahkan pada kata sekat dan pemisah pada kata membran. Jadi, kata sekat memiliki asosiasi makna dengan membran.

Data 2: Tendon (SNI 032847)

Pada bidang strukur bangunan teknik sipil, tendon adalah elemen baja misalnya kawat baja, kabel batang, kawat untai atau suatu bundel dari elemen-elemen tersebut yang digunakan untuk memberi gaya prategang pada beton. Dari makna ini ditekankan pada kata kawat. Dalam KBBI (2016) kawat adalah tali yang dibuat dari logam.

Dalam KBBI (2016), tendon adalah urat keras yang menghubungkan otot dengan sendi atau yang menghubungkan otot dengan tulang. Tendon ditekankan pada gabungan kata urat. Urat memiliki arti bagian dalam tubuh yang menyerupai benang atau tali. Pada kedua bidang itu sama-sama memiliki kata yang sama saat digali lebih dalam maknanya. Kata yang sama tersebut terjadi pada tali melalui kata kawat dan urat. Jadi, kawat berasosiasi dengan urat.

Data 3: Tulangan (SNI 032847)

Dalam bidang struktur bangunan teknik sipil, tulangan memiliki arti batang baja berbentuk polos atau berbentuk ulir atau berbentuk pipa yang berfungsi untuk menahan gaya tarik pada komponen struktur beton, tidak termasuk tendon prategang, kecuali bila secara khusus diikutsertakan. Dari sana, ditekankan kata batang. Batang dalam KBBI memiliki arti rangka sepeda kecuali roda. Kata batang jika diturunkan lagi terdapat kata rangka. Dalam KBBI (2016), tulangan memiliki kata dasar tulang yang memiliki arti rangka atau bagian rangka tubuh manusia atau binatang. Penekanan terdapat pada kata rangka. Baik bidang sturktur teknik sipil, maupun unsur istilah biologis, 
sama-sama memiliki kata rangka jika diturunkan lebih dalam maknanya dari kata tulangan. Jadi, kata batang berasosiasi dengan kata rangka.

Faktor Penyebab Terjadinya Asosiasi Makna Kata

Suatu kata dapat mengalami asosiasi makna. Satu kata yang sama bisa saja memiliki makna yang berbeda bila digunakan dalam bidang yang berbeda pula (Nursida, 2014) . Namun, makna yang terkandung dalam kata tersebut saling berasosiasi. Hal ini seperti yang terjadi pada kata diafragma, tendon, dan tulangan. Ketiga kata tersebut memiliki makna yang berbeda dalam penggunaannya ketika digunakan dalam bidang teknik sipil dan bidang biologis. Akan tetapi, pemaknaan kata-kata tersebut dalam bidang teknik masih berasosiasi dengan pemaknaan di bidang biologis. Hal ini terjadi karena makna kata dalam bidang biologis memiliki kemiripan sifat dengan apa yang dimaksud dalam bidang teknik sipil.

Adapun beberapa faktor penyebab adanya asosiasi makna pada kata diafragma, tendon, dan tulangan dalam bidang teknik sipil dengan bidang biologis adalah sebagai berikut.

1. Perkembangan dalam bidang ilmu dan teknologi. Contoh, dalam perkembangan ilmu dan teknologi bidang teknik sipil memerlukan penggunaan kata diafragma untuk menjelaskan makna atap, lantai, membran atau sistem bresing yang berfungsi menyalurkan gaya-gaya lateral ke elemen penahan vertikal. Kata diafragma dalam bidang teknik sipil berasosiasi dengan kata diafragma yang digunakan dalam bidang biologis karena memiliki kesamaan sifat dari makna diafragma tersebut, yakni bermakna sebagai pemisah.

2. Perbedaan bidang pemakaian. Setiap bidang memiliki kosakata tersendiri yang hanya dikenal dan digunakan dengan makna tertentu dalam bidang tersebut. Contoh, kata tulangan dalam bidang teknik sipil memiliki makna yang berbeda dengan kata tulangan di bidang biologis. Kata tulangan dalam bidang teknik sipil memiliki makna batang baja berbentuk polos atau berbentuk ulir atau berbentuk pipa yang berfungsi untuk menahan gaya tarik pada komponen struktur beton, tidak termasuk tendon prategang, kecuali bila secara khusus diikutsertakan. Kata tulangan digunakan dalam bidang teknik sipil berasosiasi maknanya dengan kata tulangan di bidang biologis yang bermakna rangka atau bagian rangka tubuh manusia atau binatang. Kata tulangan, baik dalam bidang teknik sipil maupun bidang biologis, berasoasi karena sama-sama merujuk pada makna rangka.

3. Pengembangan istilah. Contoh, dalam bidang biologis terlebih dahulu dikenal kata tendon, yang bermakna urat keras yang menghubungkan otot dengan sendi atau yang menghubungkan otot dengan tulang. Namun, kata tendon juga berkembang maknanya dalam bidang teknik sipil, yaitu batang baja berbentuk polos atau berbentuk ulir atau berbentuk pipa yang berfungsi untuk menahan gaya tarik pada komponen struktur beton. Jadi, suatu istilah dapat terus mengalami pengembangan istilah.

Berdasarkan pemaparan di atas dapat diketahui bahwa faktor penyebab adanya asosiasi makna dalam suatu kata atau istilah dalam bidang teknik sipil dengan bidang biologis, yakni karena perkembangan dalam bidang ilmu dan teknologi, perbedaan bidang pemakaian, dan pengembangan istilah.

\section{KESIMPULAN}

Berdasarkan hasil penelitian tersebut dapat disimpulkan bahwa kata yang digunakan pada bidang teknik sipil memiliki memiliki asosiasi makna yang mendalam dengan unsur istilah biologis. Asosisasi makna itu terlihat pada kata sekat dalam bidang struktur bangungan teknik sipil dengan membran dalam unsur istilah biologis melalui kata diafragma; 
kata kawat dalam struktur bidang bangungan teknik sipil dengan urat dalam unsur istilah biologis melalui kata tendon; dan batang dalam bidang struktur bangungan teknik sipil dengan rangka dalam unsur istilah biologis melalui kata tulangan. Faktor penyebab adanya asosiasi makna dalam suatu kata atau istilah dalam bidang teknik sipil dengan bidang biologis, yakni karena perkembangan dalam bidang ilmu dan teknologi, perbedaan bidang pemakaian, dan pengembangan istilah.

\section{Ucapan Terima kasih}

Penelitian ini mendapatkan hibah penelitian PNBP Internal skim Penelitian Dosen Pemula, UP2M, Politeknik Negeri Jakarta.

\section{Daftar Pustaka}

[1] Ayuningsih, A. (2012). Asosiasi Kata pada Mahasiswa Semester II Angkatan 2011 Sastra Inggris Universitas Padjadjaran: Kajian
Psikolinguistik. Students e-Journals Universitas Padjadjaran.

[2] Keraf, Gorys. 2010. Diksi dan Gaya Bahasa. Jakarta: Gramedia Pustaka Utama.

[3] Nursida, I. (2014). Perubahan Makna Sebab dan Bentuknya: Sebuah Kajian Historis. Jurnal Alfaz. Vol.2, No.2.

[4] Sudaryat, Yayat. (2008). Makna dalam Wacana: Prinsip-prinsip Semantik dan Pragmatik. Bandung: Yrama Widya.

[5] Sugiyono. 2012. Metode Penelitian Kuantitatif Kualitatif dan R\&D. Bandung: Alfabeta.

[6] Tarigan, Henri Guntur. 2009. Pengajaran Semantik. Bandung: Angkasa.

[7] Tarigan, Henri Guntur. 2015. Pengajaran Semantik:Edisi Revisi. Bandung: Angkasa.

[8] Widijayanto, Anang. (2015). Makna Konseptual dan Makna Asosiatif. ejournal.unnes.

Tabel 1. Pemaknaan kata Diafragma

\begin{tabular}{|c|c|c|}
\hline Kata & Makna Bidang Teknik Sipil & $\begin{array}{c}\text { Makna Leksikal (Unsur Istilah } \\
\text { Biologis) }\end{array}$ \\
\hline $\begin{array}{l}\text { Diafragma } \\
\text { (SNI 1727) }\end{array}$ & $\begin{array}{l}\text { makna atap, lantai, membran } \\
\text { atau sistem bresing yang } \\
\text { berfungsi menyalurkan gaya- } \\
\text { gaya lateral ke elemen penahan } \\
\text { vertikal }\end{array}$ & $\begin{array}{l}\text { sekat antara rongga dada dan } \\
\text { rongga perut (pada tubuh) }\end{array}$ \\
\hline \multicolumn{3}{|c|}{ Penekanan makna kata } \\
\hline Membran & $\begin{array}{l}\text { selaput, kulit tipis, atau } \\
\text { lembaran bahan tipis yang } \\
\text { merupakan pemisah }\end{array}$ & \\
\hline Sekat & & $\begin{array}{l}\text { sesuatu seperti dinding, kerai, dan } \\
\text { sebagainya untuk membatasi atau } \\
\text { memisahkan ruang (menjadi } \\
\text { berpetak-petak) }\end{array}$ \\
\hline
\end{tabular}


Tabel 2. Pemaknaan kata Tendon

\begin{tabular}{|l|l|l|}
\hline \multicolumn{1}{|c|}{ Kata } & \multicolumn{1}{|c|}{ Makna Bidang Teknik Sipil } & \multicolumn{1}{c|}{$\begin{array}{c}\text { Makna Leksikal (Unsur Istilah } \\
\text { Biologis) }\end{array}$} \\
\hline $\begin{array}{l}\text { Tendon } \\
\text { (SNI 032847) }\end{array}$ & $\begin{array}{l}\text { elemen baja misalnya kawat } \\
\text { baja, kabel batang, kawat untai } \\
\text { atau suatu bundel dari elemen- } \\
\text { elemen tersebut yang digunakan } \\
\text { untuk memberi gaya prategang } \\
\text { pada beton }\end{array}$ & $\begin{array}{l}\text { urat keras yang menghubungkan } \\
\text { otot dengan sendi atau yang } \\
\text { menghubungkan otot dengan tulang }\end{array}$ \\
\hline Urat & tali yang dibuat dari logam & Penekanan kata \\
\hline Kawat & \multicolumn{2}{|c|}{ menyerupai benang atau tali } \\
\hline
\end{tabular}

Tabel 3. Pemaknaan kata Tulangan

\begin{tabular}{|l|l|l|}
\hline \multicolumn{1}{|c|}{ Kata } & \multicolumn{1}{|c|}{ Makna Bidang Teknik Sipil } & \multicolumn{1}{c|}{$\begin{array}{c}\text { Makna Leksikal (Unsur Istilah } \\
\text { Biologis) }\end{array}$} \\
\hline Tulangan & $\begin{array}{l}\text { batang baja berbentuk polos } \\
\text { atau berbentuk ulir atau } \\
\text { berbentuk pipa yang berfungsi } \\
\text { untuk menahan gaya tarik pada } \\
\text { komponen struktur beton, tidak } \\
\text { termasuk tendon prategang, } \\
\text { kecuali bila secara khusus } \\
\text { diikutsertakan }\end{array}$ & $\begin{array}{l}\text { rangka atau bagian rangka tubuh } \\
\text { manusia atau binatang }\end{array}$ \\
\hline \\
\hline \multicolumn{2}{|c|}{ Penekanan kata } & \\
\hline Batang & rangka sepeda kecuali roda & \\
\hline
\end{tabular}

